\title{
Grief and Youth Remembered: Accessing Experiences of Historical Youth Justice through Memoir
}

By Clarissa Carden

Copyright (C) 2021 Johns Hopkins University Press. This article first appeared in JOURNAL OF THE HISTORY OF CHILDHOOD AND YOUTH, Volume 14, Issue 1, (In press, accepted 29 August 2020)

\section{Introduction}

Adult memories of childhood experiences are imperfect. However, Christine Feldman-Barrett shows that, despite the possibility for adults to make errors or engage in nostalgia or revisionism when recounting their youth, "such testimony offers an interesting bridge between how things 'really were' and how things are remembered."' While FeldmanBarrett's argument is a powerful one, the distinction between memory and objective reality is not always clear-cut. This is particularly the case where adults are recounting childhoods spent in closed institutions. The records that provide the primary means of accessing "how things "really were"" in such institutions are almost exclusively created from the perspective of administrators and staff rather than young people. ${ }^{2}$ In such contexts, the idea of an objective history that can be grasped and proven is both difficult uphold and potentially oppressive.

This article focuses on how adults remember their youthful experiences when those experiences have historically been marginalized or silenced by exploring the theme of grief in the memoirs of two former inmates of a notorious youth justice facility. Brutal: Surviving Westbrook Boys' Home ${ }^{3}$ and Westbrook ${ }^{4}$ relate the experiences of Alfred Fletcher and William Stokes, two men who were incarcerated in the Westbrook Farm Home for Boys during a roughly contemporaneous period in the late 1950s and early 1960s. This institution, 
situated in a regional area of Queensland, Australia, predominantly housed boys convicted of criminal offences during the period of Fletcher's and Stokes's incarceration.

\section{Memoir, Memory, and Public Representations of Youth Histories}

Memoirs can provide insights into the experiences of persons to whom researchers are unable to gain access. ${ }^{5}$ The experiences of former inmates of historical youth justice institutions are both valuable and difficult to capture, despite an increase in opportunities to provide testimony to official inquiries.

The 1990s brought a major shift in public discourse surrounding historical institutional care, with the abuse that took place in such institutions, and the lasting impacts on survivors, becoming a subject of international interest. ${ }^{6}$ In Queensland, while the Inquiry into Abuse of Children in Queensland Institutions (hereafter, the Forde report) provided significant evidence for the prevalence of abuse by the state, Australian public discourse was changed most dramatically through a trilogy of federal government reports - the Bringing Them Home report, the Lost Innocents report, and the Forgotten Australians report. ${ }^{7}$ These reports, which focus on the Stolen Generations, child migrants, and young people who grew up in institutional care, respectively, did much to increase public knowledge and understanding of the experiences of children who were removed from their families and raised by outsiders through the twentieth century. They also offered, for many survivors, an opportunity to speak publicly to the realities of institutional care and to describe, sometimes for the first time, the ongoing impacts of institutionalization on their lives. More recently, the Royal Commission into Institutional Responses to Child Sexual Abuse revealed the extent of child sexual abuse within historical and contemporary Australian institutions, as well as the failure of institutions to adequately manage such abuse. ${ }^{8}$ Contemporary youth justice in Australia has also been subject to specific criticism: As just one example, in 2017, the report 
of a Royal Commission into the youth justice system of the Northern Territory revealed "systemic and shocking failures." Despite initial intense public interest, the ultimate response to this investigation was muted.

While these inquiries' specific terms of reference have differed, all have involved large-scale analysis of systematic failures and abuses. The Forde report, for example, which was the most influential in relation to recording the experiences of Westbrook inmates, focused on institutions established under four specific pieces of legislation, examining past institutional abuse and reviewing current systems of legislation. ${ }^{10}$ This report is notable for devoting a chapter to "Correctional Facilities,"11 much of which focuses on Westbrook. However, it follows the broader trend of reviews into historical abuse in the Australian context, which have generally had broad purviews. The reports have sought and used survivors' individual testimony, but individual histories themselves have not been the focus of analysis.

In this milieu, public forms of testimony offer insight into the lived experience of childhood and youth within the closed walls of historical institutional care. Written submissions to inquiries, quotations from oral testimony contained within reports, and the recollections of survivors expressed in memoirs all serve to enhance and correct a historical record that has been dominated by the documents created by institutions themselves. This additional form of evidence becomes even more vital in the case of institutions from which minimal documentation is available.

The evidence of survivors of institutional care can also provide insight into what came after experiences of care ended - the way in which youth is remembered as well as the impact of young people's institutionalization on the adults they became. Such accounts are valuable, not least because they speak directly to some of the presumed purposes of care: to provide a positive environment in which to grow up and to develop good and moral adults. In the case 
of young people who were institutionalized in justice facilities, these further speak to the overarching aim of reformation that was ostensibly at the heart of such institutions.

Despite increasing understanding and acceptance of the trauma suffered by former residents of childhood institutional care, former residents of juvenile justice facilities such as Westbrook face additional stigma. In order to be admitted to this institution, the vast majority of young people were committed by a court. While in its early years the institution housed many children declared by a court to be neglected, rather than sentenced for criminal offences, when during which Fletcher and Stokes were incarcerated it was in a period of transition. By 1961, almost all of the boys at Westbrook had been convicted of a crime and after that year, the institution held only young people, usually fifteen years or older, who were either convicted or on remand. Both Fletcher and Stokes were sent to Westbrook for minor criminal offences. ${ }^{12}$

In Australia, even today, the National Redress Scheme for Institutional Child Sexual Abuse clearly differentiates between the survivors of institutional sexual abuse who have committed serious crimes and those who have not - a decision that continues to be viewed as contentious. The National Redress Scheme for Institutional Child Sexual Abuse Act states that a person who has been sentenced to imprisonment for five years or longer, either before or after making an application for redress, is not eligible for redress under the scheme. The operator of the scheme may determine that such a person is entitled to redress only if doing so would not "bring the scheme into disrepute" or impact public confidence. ${ }^{13}$ While neither sexual abuse nor restitution is a focus of the accounts detailed here, this official attitude to criminality suggests a prevalent response to institutional suffering that minimizes or ignores the experiences of those who have committed criminal offences. In order to be recognized as true victims, former residents of institutional settings must be, in a sense, “pure.” Juvenile offenders do not fit neatly into categorizations of innocent children and abuse victims. Erica 
Bouris, in Complex Political Victims, argues for the recognition of victims who do not meet idealized standards of innocence and who may have committed criminal or violent acts. ${ }^{14}$ Swain applies this concept to those who, as children, have taken part in abusive actions within Australian institutions while themselves being victims of abuse. She identifies that revelations of abusive actions on the part of victims are often seen to damage claims to justice and are thus refuted, demonstrating the continuing challenges in recognizing the complexity of victimization in childhood institutions. ${ }^{15}$

As former residents of a youth justice institution, Fletcher and Stokes speak from a position of double marginalization. They belong to the category of persons who have experienced historical childhood institutionalization, but they are also individuals who have been involved with the criminal justice system. They are, in Bouris's sense, complex victims. For this reason, their accounts, including their descriptions of life inside Westbrook and the impact of their experiences on their later lives, are particularly valuable. They serve to provide evidence not only of the often-terrible conditions in which residents of historical juvenile justice facilities lived, but also of the extent to which the grief of ex-inmates continues to be disenfranchised.

\section{Westbrook Farm Home for Boys}

The Westbrook Farm Home for Boys is a significant site for study. While the institution existed under that name only between the years 1919-1966, its pedigree is far longer, with some variation of the same institution remaining a critical part of Queensland's youth justice system from 1871-1994. ${ }^{16}$ This was a rural institution that had formerly been known as a reformatory school and which, like a similar institution in New South Wales, took on the name "Farm Home" in the early twentieth century in order to denote an increased focus on rural training. ${ }^{17}$ During the institution's earliest years, it held a fairly even mix of boys who 
were convicted of crimes and those who were found to be neglected and in need of state care. ${ }^{18}$ While records for the period during which Fletcher and Stokes were incarcerated are not available, the 1961 Schwarten report, which features in both of the studied memoirs, notes that at the time of the report's publication, only one child was incarcerated without having been convicted of an offence. ${ }^{19}$

While the longevity of the institution alone renders it worthy of serious scholarly inquiry, it is also notable for the evidence of serious harm done to its inmates. The Forde report stated that "Westbrook stood at the apex of the 'correctional' system for boys in care and was without doubt its most feared institution." ${ }^{20}$ It went on to note that the mistreatment of boys within the institution was well known, and that " $[\mathrm{t}]$ he possibility of suffering some form of abuse at the institution was the greatest dread for the majority of boys in danger of being ordered to undergo a period of training there."21

This was particularly true during the years 1952-1962, when the institution was under the command of Roy Golledge, a superintendent known for his harsh and often abusive punishments, to the extent that the Forde report described Westbrook, during his time as superintendent, as "the most extreme example" of a culture of "gross excesses in physical abuse in some institutions, beyond any acceptable boundary in any period."22

A mass escape in 1961, involving approximately thirty-six boys, prompted a major inquiry into the conditions at the institution, conducted by a stipendiary magistrate, Mr. A. E. Schwarten. ${ }^{23}$ His findings expose a culture of harsh and improper punishment, including both corporal punishment and more inventive punishments, as well as poor conditions and treatment of inmates. ${ }^{24}$ The Schwarten report, the Forde report, and, to a lesser extent, the Forgotten Australians report provide valuable supporting evidence that the authors of the studied memoirs employ to justify their claims about conditions in the institution. 


\section{Brutal and Westbrook: Similarities and Differences}

While Brutal and Westbrook describe the same institution during a broadly similar historical moment, the two memoirs are distinct in terms of content and style. Fletcher and Stokes speak from very different positions, and their experiences in the institution are colored by personal characteristics, including sexual preferences, as well as the way in which their lives played out after their period of incarceration.

\section{Alfred "Crow" Fletcher and Brutal}

Brutal was originally published as The 'Brook. The text is related "as told to" author Cheryl Jorgensen. Jorgensen, who was previously best known for works of fiction, including crime novels and a young-adult novel, was approached by Fletcher to aid him in writing his story. She has since produced a work on the life of another former Westbrook inmate that is not here explored due to the brevity of its discussion of the institution. Despite the coconstruction of Brutal, it is written in Fletcher's voice, using a first-person, colloquial style that serves to position the work as Fletcher's own memoir rather than a biography authored by another. ${ }^{25}$

Fletcher himself is an outspoken advocate for former inmates of Westbrook and has participated in government inquiries and spoken at the National Museum of Australia. ${ }^{26}$ His memoir arguably represents an additional form of activism and truth-telling in relation to this institution. He entered Westbrook in 1960 and was present for both the mass escape of 1961 and the Schwarten inquiry.

William "Billy” Stokes and Westbrook

Unlike Brutal, Westbrook is attributed to a sole author. William Stokes is a minor public figure in Queensland, a former editor of the union movement-affiliated Port News, and who 
has been associated with major criminal offences. Most notably, he was linked to a sensational crime in the 1970s, the firebombing of the Whiskey Au Go Go nightclub in Brisbane and convicted — wrongly, he states — of murder. ${ }^{27}$ Stokes's public profile is thus connected more to his life after Westbrook than his experience of institutionalization.

Westbrook is written in a conventional style, with accessible, plain prose. Unlike Brutal, it does not make use of colloquial voice. Stokes entered Westbrook in 1958, shortly before his fifteenth birthday. He was released prior to the 1961 escape, but his narrative of the escape, which provides an imagined account of the thoughts and feelings of key protagonists, nonetheless forms the climax of his memoir. This pivotal moment in the institution's history, and the inquiry that followed, serve to justify and support the claims Stokes makes about the conditions under which he spent his time in the institution.

A final key distinction between Stokes's account of Westbrook and Fletcher's is that Stokes describes being party to sexual liaisons within the institution. Whereas Fletcher's memoir notes that such liaisons had occurred, Stokes's depiction demonstrates an intimate familiarity with the unwritten rules around sex and, indeed, courtship and the means through which inmates kept such relationships from the knowledge of staff members.

\section{Plot and Content}

The two memoirs share a similar plot. Each begins by providing a sense of the author's life prior to entering Westbrook. Fletcher's memoir reflects far more on his early life, exploring his relationships with family members and describing his admission to other Queensland institutions. He recalls that, at age thirteen, he was threatened with the prospect of being charged as a neglected child and sent to Westbrook, marking the institution's menacing reputation from the beginning of the text. Stokes, by contrast, spends on chapter on his own background before describing his sentence and admission to Westbrook. 
Despite these initial differences, both Fletcher and Stokes spend the majority of their memoirs recounting the conditions they experienced in the institution and the abuse they either experienced or saw perpetrated on other inmates. They both describe the regimentation of the institution and the way in which it dictated even their most basic needs. Fletcher describes parading past the officer on duty after washing his hands and face so that he could be inspected. Stokes describes the regimented process of toileting, always observed. ${ }^{28}$

They both describe the experience of having their own clothing taken from them and being issued clothing from the institution's store. Stokes also recalls that their clothing was not set aside for them-instead, it was reissued to other inmates. Having been delivered straight from court to the institution, he said that "[i]t came as a surprise to notice that my tailor-made trousers had been issued to someone else; clothes that I had earlier selected as ideal to wear to court." 29

Both memoirs also describe the memoirists' own transgressions and conflicts with the figures of authority in the institution. These stories of transgressions serve to highlight the cruelty with which infractions, whether real or imagined, minor or serious, were treated at Westbrook. Fletcher's experience was marked by the early escape of Robin Parnell, a fellow inmate who had been his good friend prior to entering the institution. While Fletcher denied knowledge of the escape, he could not avoid being punished under suspicion that he had been informed and failed to prevent its occurrence. He describes being publicly strapped by Golledge until the man was exhausted, stating that "[y]ou were supposed to sing out 'Ooh Sir!' every time Golledge hit you. I didn't know that. If you didn't sing out, he just kept beltin' you." ${ }^{30} \mathrm{He}$ also describes, another, much crueler and more unusual punishment that he encountered after his own escape attempt. The Path is described in both memoirs and also in the Schwarten and Forde reports. ${ }^{31}$ Fletcher's description is powerful: 
It consisted of six parallel tracks, each twenty meters long and about two meters apart. There was a post at both ends of each track. You had to walk up and down between those posts all your spare time. You still had to do your day's work, but when the others knocked off, you went on the Path.

You had to keep on walkin' quick. If you slowed down, they'd put a sergeant at each end to give you a smack in the head until you went quick enough for their likin'. If they went to the trouble of sendin' a couple of sergeants down, you got quite a few smacks, no matter how fast you went. ${ }^{32}$

For boys who were only issued one pair of boots and were not able to regularly clean their clothes, this punishment was likely to cause additional pain in the form of blisters and increased poor hygiene. While both memoirs reflect on the extreme cruelty inflicted within the institution, Stokes also reflects upon less dramatic experiences of cruelty. He recalls how he became attached to a cow he was solely responsible for milking. When the institution ran out of meat, he was shocked to discover that the cow, who he regarded as his pet, was killed suddenly and in front of him, and he was expected to load pieces of her onto a dray for transportation. He was then served the cow at dinner. He reflected that "[o]nly yesterday I had patted her and looked into her placid eyes. Now she was on my plate with vegetables in a stew I was expected to eat." 33

The climax of both memoirs comes with the mass escape of 1961 - the event that led to the production of the Schwarten report and which opened the institution up to increased public scrutiny. Fletcher took part in this escape and was one of a small handful of boys incarcerated in Boggo Road jail, an infamous adult prison in Queensland, as a result of his actions while outside the institution. Stokes was by that period home with his family in the capital city of Brisbane, but the focus of his account was the events that occurred in the 
institution itself. The difference in approach to the escape highlights a significant difference between the two memoirs-Fletcher's approach tends to focus only on events that he himself witnessed or could verify, while Stokes takes a more creative approach, suggesting what people thought, saw, and felt during an event that he did not witness firsthand.

\section{The Right to Grieve}

Grief is a key theme in both Stokes's and Fletcher's memoirs. However, the grief they express is one that is disenfranchised - a form of grief which, while it may be deeply felt, is nonetheless not socially recognized. Disenfranchised grief occurs where the loss that is grieved is not viewed as a real loss, and thus the type of social support that may otherwise be accessible to the griever is absent. ${ }^{34}$ Attig argues that the disenfranchisement of grief is a social failure with serious consequences:

Some have urged that it is a failure of empathy, which it surely is. But it is not merely that; it is deeper and more serious. Disenfranchisement of grief is a political failure involving both abuse of power and serious neglect. And it is an ethical failure to respect the bereaved both in their suffering and in their efforts to overcome it and live meaningfully again in the aftermath of loss. ${ }^{35}$

While the theory of disenfranchised grief was initially applied predominantly to unrecognized death losses, it has been expanded to encompass non-death losses that nonetheless result in grief. ${ }^{36}$ In the studied memoirs, Fletcher and Stokes relate numerous non-death losses that they attribute to the incarceration and abuse of boys in Westbrook.

One example shared across both accounts is the story of a young man with the nickname Schongie. According to both authors, Schongie was a boy whose life had been marked by poverty but who had proven himself to be good-natured and dependable while 
within Westbrook. According to Fletcher, Schongie had the unpleasant task, within the institution, of being both the "hose boy," who moved sprinklers around the planted areas, and the "shit ringer," who was responsible for emptying the toilers of warders. According to Stokes, Schongie was "so docile that he would never even argue with a soul." 37 As a result of his good behavior, both memoirists state, the boy was allowed to leave the institution and to be "hired out" to a farmer - a common practice wherein children from institutions would be sent to live and work with families for the remainder of their sentence.

Fletcher recounts later meeting Schongie, quite by accident, in a jail cell. While Fletcher was being held for activities during an attempted escape from Westbrook, Schongie was there for committing a murder. He recalls being told that the farmer Schongie had been sent to assist had threatened that, if he did not have sex with him, Schongie would be returned to Westbrook. ${ }^{38}$ Appealing to Stokes as a corroborating witness, Fletcher writes of Schongie:

He was an inspiration to everybody. He was not a violent person, he wouldn't hurt a fly. He always made people feel happy and anybody who knew him in Westbrook or in Boggo Road would say the same thing, he was a good man. Me mate Bill Stokes will tell you that, you know, anybody. ${ }^{39}$

For Fletcher, the event was evidence that Westbrook had transformed his friend into something different - that the dual impact of the brutal treatment inmates suffered in the institution and the fear of returning was sufficient to turn a quiet, docile person into a murderer. He states that "I reckon it was Westbrook that killed that farmer, not Schongie. We was walkin’ time bombs."40

Bailey argues convincingly that disenfranchised grief can occur in the spouses of persons who, through conviction, are given the label "sex offender." 41 This is not a physical loss through death but a psychosocial loss of an individual who was known or believed to be 
known. In the story of Schongie, both Fletcher and Stokes express a form of grief for a friend who had done something they would have considered impossible. For them, however, the grief was doubled by the belief that they had not only lost the person they thought they knew, but that the person they in fact did know had been irrevocably damaged.

This is not the only narrative in which the two memoirs reflect on grief for a fellow inmate whose life was altered as a result of their experiences in Westbrook. Both Fletcher and Stokes describe another individual, who, unlike Schongie, was not a friend, but who they suggest was transformed by his treatment at Westbrook into a killer. According to Fletcher, he was "just an innocent kid" who was beaten up by inmates and staff alike. Both Fletcher and Stokes state that Boots, sometime after his discharge from Westbrook, suddenly committed the mass murder of a farming husband and wife and their livestock. Both add that he killed an officer while in jail and died young of a massive heart attack. ${ }^{42}$

Stokes ends his memoir with an epilogue wherein he describes the fates of many of the young people he met in the institution. While he notes that some former inmates went on to live normal lives, the vast majority of those he describes experienced some form of trauma or tragedy. ${ }^{43}$ In doing so, he powerfully expresses a sentiment that Fletcher sums up in saying that "Westbrook is responsible for a lot of bad things that happened."

The memoirs therefore reveal a grief for the loss of friends and acquaintances who, even where they have not died, have been irrevocably changed by the circumstances of their incarceration. They also reveal a grief for the memoirists' own losses—of years, of opportunities, and of identity. Disenfranchised grief has been recognized as a possibility and indeed a reality in the child welfare system. The removal of young people from their families of origin, often in traumatic circumstances, may contribute to experiences of grief in young people themselves, but also in their birth parents and even, when they are removed, in their foster carers. Mitchell explores the non-death grief of young people in foster care situations, 
highlighting the significance of trauma that can occur not just through actual abuse, but also as a result of separation from family and friends. Foster care is intended as a temporary situation, which Mitchell shows may nonetheless lead to losses of identity and community. The theory has also been applied to the experiences of birth mothers whose children were taken into care or adopted and foster carers experiencing the end of placements. ${ }^{45}$

While not using the terminology of disenfranchised grief, recent scholars have highlighted the need for leavers of institutional care to have access to documentation that allows them to develop a life narrative and to make sense of their childhood experiences. ${ }^{46}$ Such records allow survivors of institutional care to construct an understanding of their identity and the ways in which their lives have been impacted by institutionalization.

However, they also form an identity in response to public narratives around the institutions of which they were part—an identity that shifts in response to changes in the public narrative surrounding the circumstances of their upbringing. The circumstances under which Fletcher and Stokes came to be institutionalized - the fact that they were juvenile offenders rather than "innocent" children who came to enter care due to poverty, bereavement, or other conditions outside of their control—-renders both their identity as survivors and narratives of grief difficult to sustain as a socially recognized fact. The memoirs may therefore be read as a response to grief for a lost youth, a lost identity, and lost opportunities that stems from the social stigma attached both to criminal activity and more specifically to institutionalization in Westbrook itself. Fletcher described the impact of his time in Westbrook in an address at the National Museum of Australia:

[W]e have been on trial since we went there and when we got out. When you applied for a job, if they knew you were from Westbrook you would not get that job. If you went to court for any misdemeanor or small thing, you would always say you were in Westbrook and then you ran away, and charges kept 
accumulating. So I suppose the judges looked at it and thought he's a criminal. These all accumulated while you were in Westbrook, all these things against you. ${ }^{47}$

This sense of being on trial—of being continuously punished not only for the original offence, but also for the crime of being associated with Westbrook, and, in Fletcher's case, the crime of eventually escaping that institution — is evident in both memoirs as a determining factor in the afterlives of former inmates. This judgment and social stigma has contributed to the disenfranchisement of the memoirists' grief and to their difficulty in staking a claim to their position as victims.

Despite this disenfranchisement, both Fletcher and Stokes make statements that demonstrate that they do experience grief for the loss of the lives they could have lived had they not been incarcerated at Westbrook. Stokes describes letters confiscated by Golledge that made him feel as though he had been forgotten by his family and friends. He also, however, describes his good fortune at being able to return home to a loving family who could provide him with good food, a comfortable place to live, and access to a car. ${ }^{48}$ Fletcher, in his role as a public advocate for other former residents of Westbrook, has been far more explicit about the impact of the institution and the way in which it had shaped his life for the worse. In 2011, he said:

Yes, I have been in Westbrook Reformatory for Boys and Boggo Road Jail and Silky Oaks Religious Home and Riverview Salvation Army Boys Home. Yes, I have attempted suicide and have gone through life as if two people in one. The real me is what you are seeing now. The other is still suffering from Westbrook. This wasn't the way to break children in those days. It was accepted in those 
days. But in my opinion it wasn't accepted — not everybody was doing all this to their children. ${ }^{49}$

Fletcher's statement - that "breaking" children through the ill treatment he received at Westbrook was accepted, but not for all children — speaks to the way in which the grief expressed in the memoirs is disenfranchised. In Fletcher's perspective - and indeed in Stokes's view - the treatment of boys at Westbrook was accepted solely because they were offenders and outcasts. At the same time, the institution was closed and secretive - $\mathrm{a}$ fact addressed in the memoirs through the truth claims made by the former inmates.

\section{Truth Claims}

The most significant way in which the Fletcher and Stokes seek to claim legitimacy for their experiences in Westbrook and for the loss they experienced as a result is through truth claims. In insisting that the stories they tell are truth, the former inmates refer not only to their own inherent trustworthiness but to the extant documentation of the institution and the treatment experienced by inmates therein. In this sense, Fletcher, Stokes, and their contemporaries in Westbrook are fortunate. Records describing the conditions in institutions of this nature during this period are rare. There are a range of reasons for this-much material has been declared secret and can only be accessed by survivors through a complicated request process. This material, even if survivors can access it, is not likely to reflect those aspects of institutional life that are most important to their experiences. The reports generated about young people in institutions were intended to suit the needs of staff and administrators, not the young people themselves. As such, they are often unsatisfyingly brief and impersonal and may present a view of former residents that does not mesh with their own memories. ${ }^{50}$ Other records have been lost or destroyed through natural disaster. In Queensland, mass flooding in 
1974 had a serious impact on the state's archival holdings. Further, record keeping was not always consistent or accurate. However, the Schwarten report, produced in response to the mass escape both authors describe, supports many of the significant claims the memoirists make about the conditions and ill treatment they experienced at Westbrook.

Both authors refer to the Schwarten report, with Fletcher going so far as to publish several excerpts at the end of his text, and both draw on additional sources for their statements. Fletcher's memoir is prefaced by text from former Australian prime minister Kevin Rudd's apology to victims of abuse in historical institutional care. His book also contains a foreword by Senator Andrew Murray, whose position on the committees responsible for the Lost Innocents report, the Forgotten Australians report on historical institutional care, and as a Royal Commissioner on the recent inquiry into institutional responses to child sexual abuse, alongside his personal experience as a survivor of child migration to what was then Rhodesia, render him an authority on the abuse of Australian young people in historical institutions. ${ }^{51}$

Stokes begins his memoir with an acknowledgement of his sources. He states that his narrative is compiled from documents obtained under freedom of information laws and the Schwarten report. He also acknowledges the State Library of Queensland and Queensland Newspapers Pty Ltd for their support in obtaining additional records. This acknowledgement of sources bolsters his claims to an account that is historically true.

Existing research, as well as the reports of government-sponsored commissions into historical institutional care, have drawn on testimonies, oral histories, and, occasionally, published memoirs. This evidence is constructed by adults remembering their childhoods, often at a distance of several decades. It has also contributed to some suspicion attached to "retrospectively constructed accounts" that "the application of increasingly sophisticated theories of remembering has done little to assuage." 52 There is also evidence that the authors 
of biography or autobiography have, in some cases, sought to rescript their identity in order to engage with accessible discourses and identities. For example, Smith found that the authors of British criminal autobiographies positioned their lives in relation to the social construct of the entrepreneur. ${ }^{53}$ The types of recognizable narratives that are available to former residents of institutional care presume a type of perfect child-as-victim, excluding victims who are also criminal offenders, such as Fletcher and Stokes.

There are real questions about the extent to which an account constructed many years later can be said to be truthful. The fallibility of memory, the broader social context in which a memoir is constructed, and even literary conventions can shape or alter the narrative told. However, a memoir is not valid only insofar as it is wholly accurate and truthful. Indeed, the concept of a complete and accurate truth is a potentially oppressive one, privileging those who have the capacity to produce the documents that become history. Through writing memoir, authors are able to claim "authority through experience and voice." 54 The truths expressed through memoir are truths as they are remembered. As such, memoirs have the capacity to provide insight into the remembered truth of persons whose experiences are not reflected in the official historical record. Memoirs written years later also reveal those aspects of the past that are viewed by the authors as most significant in forming their adult self.

The experiences related by Fletcher and Stokes are shaped by the expectations of the genre and the format required for publication. Memoir allows authors to relate their own truths and to demand a level of sustained attention that is not possible in reports based on written testimony. Nonetheless, published memoirs are shaped by publishers, editors, and, in the case of Fletcher's work, a co-author. Thus, while the memoir genre arguably provides survivors with an opportunity to relate their experiences on their own terms, it should not be imagined to provide a form of "pure" truth or memory. 
Neither author claims to remember accurately every aspect of their period of institutionalization. Such a claim would be impossible to sustain — who among us can remember full years of our life, at a remove of several decades, with perfect accuracy? They claim, instead, to provide an accurate representation of what occurred at Westbrook and, more importantly, what it did to them and to others.

As a result, the themes of grief and truth are intrinsically bound in these works. By asserting the substantive truth of their accounts, Stokes and Fletcher lay claim to the validity of the grief they experienced and continue to experience. They assert their expertise as survivors of the historical period they described, as participants in a public narrative, and as researchers with documentary materials to support their claims. Fletcher provides the clearest example of this type of truth claim at the conclusion of his memoir, stating:

Anyway, that's me story. I've told it and no one can call me a liar because I've got the evidence to prove all I've said. When you've been institutionalized it's hard to settle down to what might be called a normal life. You see things different. But I guess I might be one of the lucky ones who got out of Westbrook and lived to tell the tale. A lot of the boys that was in there with me are dead. In later years they suicided or the grog got 'em, same thing I suppose. ${ }^{55}$

Here, the intersection of truth claims and expressions of grief comes to the fore. In claiming that he has evidence to prove the veracity of his account, Fletcher justifies his argument that former inmates of Westbrook have suffered loss, not because they committed criminal offences, but because they spent time in an environment which was inherently damaging and abusive. In addressing the outcomes of former Westbrook inmates, Fletcher and Stokes highlight the loss caused by the institution and, intrinsically, the political failure inherent in the lack of social recognition for this type of grief. ${ }^{56}$ 


\section{Conclusion}

Despite growing recognition of the damaging impacts of historical childhood institutionalization on former residents, the stories of young people who were institutionalized as a result of criminal activity remain marginalized. Criminality continues to be seen as a valid reason for institutionalization, and the abuse suffered in facilities such as the Westbrook Farm Home for Boys does not have the same social recognition and status as abuse suffered in other contexts wherein young people can be perceived as entirely “innocent." As demonstrated by media reports of abuse in the Northern Territory's youth justice system in 2016 and of children held in adult watch houses in Queensland in 2019, young people on remand or convicted of criminal offences continue to experience mistreatment, neglect, and improper care in Australia. ${ }^{57}$ The status of the young people affected as offenders, or accused offenders, renders them, like Fletcher and Stokes, complex victims.

In the context of continuing problems in youth justice, the voices of survivors are essential. In Brutal and Westbrook, Fletcher and Stokes speak openly about their experiences and acknowledge the harm that occurred to them and to others in historical youth justice. In doing so, they demand that the unique harm and loss that occurred in these settings be recognized in public narratives of historical institutional care.

These accounts demonstrate the significance of the memoirs written by adults to historical inquiry into the experiences of youth. In relating their experiences of abuse, suffering, and grief, Fletcher and Stokes reveal the aspects of their youth in incarceration that they view as most influential and significant, adding the otherwise inaccessible voice of former child inmates to existing archival and other documentation. 


\section{Notes}

${ }^{1}$ Christine Feldman-Barrett, "Back to the Future: Mapping a Historic Turn in Youth Studies," Journal of Youth Studies 21, no. 6 (July 3, 2018): 239, https://doi.org/10.1080/13676261.2017.1420150.

${ }^{2}$ Shurlee Swain and Nell Musgrove, "We are the Stories We Tell about Ourselves: Child Welfare Records and the Construction of Identity among Australians Who, as Children, Experienced out-of-Home 'Care,'” Archives and Manuscripts 40, no. 1 (March 2012): 414, https://doi.org/10.1080/01576895.2012.668840; Kaisa Vehkalahti, “Dusting the Archives of Childhood: Child Welfare Records as Historical Sources," History of Education 45, no. 4 (July 3, 2016): 430-45, https://doi.org/10.1080/0046760X.2016.1177610.

${ }^{3} \mathrm{Al}$ "Crow" Fletcher and Cheryl Jorgensen, Brutal: Surviving Westbrook Boys Home (Sydney: New Holland Publishers, 2010).

${ }^{4}$ William Stokes, Westbrook (Sydney: Pan Macmillan Australia, 2010).

${ }^{5}$ Lhe Kleinreesink and Joseph MML Soeters, "Truth and (Self) Censorship in Military Memoirs," Current Sociology 64, no. 3 (May 2016): 373-91, https://doi.org/10.1177/0011392115590613.

${ }^{6}$ Kathleen Daly, “Conceptualising Responses to Institutional Abuse of Children," Current Issues in Criminal Justice 26, no. 1 (2014): 5-29; Johanna Sköld, "Historical Abuse-A Contemporary Issue: Compiling Inquiries into Abuse and Neglect of Children in Out-ofHome Care Worldwide," Journal of Scandinavian Studies in Criminology and Crime Prevention 14, supp. 1 (May 2013): 5-23, https://doi.org/10.1080/14043858.2013.771907. 
${ }^{7}$ Commission of Inquiry into Abuse of Children in Queensland Institutions, "Report of the Commission of Inquiry into Abuse of Children in Queensland Institutions" (Brisbane: Queensland Government, May 31, 1999); National Inquiry into the Separation of Aboriginal and Torres Strait Islander Children from Their Families, "Bringing Them Home" (Commonwealth of Australia, 1997); Senate Community Affairs References Committee, "Lost Innocents: Righting the Record-Report on Child Migration" (Canberra:

Commonwealth of Australia, 2001); Senate Community Affairs References Committee, "Forgotten Australians: A Report on Australians Who Experienced Institutional or Out-ofHome Care as Children" (Canberra: Commonwealth of Australia, 2004).

${ }^{8}$ P. McClellan et al., "Final Report of the Royal Commission into Institutional Responses to Child Sexual Abuse" (Canberra: Royal Commission into Institutional Responses to Child Sexual Abuse, 2017).

${ }^{9}$ Margaret White and Michael Gooda, "Report of the Royal Commission and Board of Inquiry into the Protection and Detention of Children in the Northern Territory, Volume 1" (Darwin: Northern Territory Government, 2017), 9.

${ }^{10}$ Commission of Inquiry into Abuse of Children in Queensland Institutions, "Report of the Commission of Inquiry into Abuse of Children in Queensland Institutions," 1.

${ }^{11}$ Commission of Inquiry into Abuse of Children in Queensland Institutions, 121-77.

${ }^{12}$ Clarissa Carden, "Reformatory Schools and Whiteness in Danger: An Australian Case," Childhood, 2018, 1-11, https://doi.org/10.1177/0907568218775177; Alan Savige, “'Naughty' Boys: The Education of Reformatory School Boys at Lytton 1881-1899," Journal of the Royal Historical Society of Queensland 15, no. 1 (1993): 33-48; AE Schwarten, "Report: Westbrook Farm Home for Boys Inquiry," Inquiry (Brisbane: Queensland Government, September 27, 1961); Commission of Inquiry into Abuse of 
Children in Queensland Institutions, "Report of the Commission of Inquiry into Abuse of Children in Queensland Institutions."

${ }^{13}$ Community Affairs Legislation Committee, "National Redress Scheme for Institutional Child Sexual Abuse Bill 2018 [Provisions] [and] National Redress Scheme for Institutional Child Sexual Abuse (Consequential Amendments) Bill 2018 [Provisions]" (Canberra: Australian Government, 2018), sec. 63.

${ }^{14}$ Erica Bouris, Complex Political Victims (Bloomfield, CT: Kumarian Press, 2007).

${ }^{15}$ Shurlee Swain, “Both Victim and 'Perpetrator': Finding a Voice before Inquiries into Historical Abuse in Out-of-Home Care," International Journal of Transitional Justice 12, no. 3 (November 1, 2018): 464-78, https://doi.org/10.1093/ijtj/ijy015.

${ }^{16}$ Lee Butterworth, "Farm Home for Boys, Westbrook (1919-1966)," Document, 2014, https://www.findandconnect.gov.au/guide/qld/QE00533.

${ }^{17}$ Clarissa Carden, "From Reformatory to Farm Home: Developments in Twentieth-Century Juvenile Justice," Cultural and Social History, 16, no. 3 (March 28, 2019): 1-16, https://doi.org/10.1080/14780038.2019.1594499.

18 "Queensland State Archives Item ID532416, Register-Admissions" (Queensland State Archives, 1906, 1871), Queensland State Archives, http://www.archivessearch.qld.gov.au/Search/ItemDetails.aspx?ltemld=532416.

${ }^{19}$ Schwarten, "Report: Westbrook Farm Home for Boys Inquiry," 17.

${ }^{20}$ Commission of Inquiry into Abuse of Children in Queensland Institutions, "Report of the Commission of Inquiry into Abuse of Children in Queensland Institutions," 124.

${ }^{21}$ Commission of Inquiry into Abuse of Children in Queensland Institutions, 124.

${ }^{22}$ Commission of Inquiry into Abuse of Children in Queensland Institutions, iv.

${ }^{23}$ Schwarten, "Report: Westbrook Farm Home for Boys Inquiry," 1. 
${ }^{24}$ Schwarten, "Report: Westbrook Farm Home for Boys Inquiry."

${ }^{25}$ Alfred Fletcher and Cheryl Jorgensen, The 'Brook (Frenchs Forest, N.S.W.: New Holland, 2006); Cheryl Jorgensen, "About Cheryl," Cheryl Jorgensen author blog, 2010, http://www.cheryljorgensen.com.au/about/; Cheryl Jorgensen, The Taint (Moorooka, Qld.: Boolarong Press, 2008).

${ }^{26}$ Fletcher and Jorgensen, The 'Brook; Adele, "Inside Westbrook," August 24, 2011, National Museum of Australia, Inside Blog: Life in Children's Homes and Institutions; Alfred Fletcher, "Life inside Westbrook Children's Home, from the perspective of a survivor, " interview by Adele Chynoweth, Transcript, September 1, 2011, National Museum of Australia, Inside Blog: Life in Children's Homes and Institutions; Fletcher and Jorgensen, Brutal

${ }^{27}$ Stokes, Westbrook, 432.

${ }^{28}$ Fletcher and Jorgensen, Brutal, 131; Stokes, Westbrook, 15.

${ }^{29}$ Stokes, Westbrook, 44.

${ }^{30}$ Fletcher and Jorgensen, Brutal, 61.

${ }^{31}$ Schwarten, "Report: Westbrook Farm Home for Boys Inquiry," 26; Commission of Inquiry into Abuse of Children in Queensland Institutions, "Report of the Commission of Inquiry into Abuse of Children in Queensland Institutions," 127.

${ }^{32}$ Fletcher and Jorgensen, Brutal, 68.

${ }^{33}$ Stokes, Westbrook, 103-5.

${ }^{34}$ Kenneth J Doka, "Disenfranchised Grief," in Living with Grief: Loss in Later Life, ed. Kenneth J Doka (Washington, DC: Hospice Foundation of America, 2002), 159-68; Kenneth J Doka, “Disenfranchised Grief," Bereavement Care 18, no. 3 (December 1999): 37-9, https://doi.org/10.1080/02682629908657467; Thomas Attig, “Disenfranchised 
Grief Revisited: Discounting Hope and Love," OMEGA-Journal of Death and Dying 49, no. 3 (November 2004): 197-215, https://doi.org/10.2190/P4TT-J3BF-KFDR-5JB1; Anu Harju, "Socially Shared Mourning: Construction and Consumption of Collective Memory," New Review of Hypermedia and Multimedia 21, no. 1-2 (April 3, 2015): 123-45, https://doi.org/10.1080/13614568.2014.983562.

${ }^{35}$ Attig, "Disenfranchised Grief Revisited," 201.

${ }^{36}$ Monique B. Mitchell, “'No One Acknowledged My Loss and Hurt': Non-Death Loss, Grief, and Trauma in Foster Care," Child and Adolescent Social Work Journal 35, no. 1 (February 2018): 1-9, https://doi.org/10.1007/s10560-017-0502-8; Damien W. Riggs and Stacey Willsmore, "Experiences of Disenfranchised Grief Arising from the Unplanned Termination of a Foster Placement: An Exploratory South Australian Study," Adoption \& Fostering 36, no. 2 (July 2012): 57-66, https://doi.org/10.1177/030857591203600206; Alex Gitterman and Carolyn Knight, "Non-Death Loss: Grieving for the Loss of Familiar Place and for Precious Time and Associated Opportunities," Clinical Social Work Journal 47, no. 2 (September 17, 2018): 147-55, https://doi.org/10.1007/s10615-018-0682-5.

${ }^{37}$ Fletcher and Jorgensen, Brutal, 62-4; Stokes, Westbrook, 208.

${ }^{38}$ Fletcher and Jorgensen, Brutal, 83.

${ }^{39}$ Fletcher and Jorgensen, 84.

${ }^{40}$ Fletcher and Jorgensen, 90.

${ }^{41}$ Danielle J. S. Bailey, “A Life of Grief: An Exploration of Disenfranchised Grief in Sex Offender Significant Others," American Journal of Criminal Justice 43, no. 3 (September 2018): 641-67, https://doi.org/10.1007/s12103-017-9416-4.

${ }^{42}$ Fletcher and Jorgensen, Brutal, 69, 94; Stokes, Westbrook, 326-430.

${ }^{43}$ Stokes, Westbrook, 429-32. 
${ }^{44}$ Fletcher and Jorgensen, Brutal, 92.

${ }^{45}$ Mitchell, “'No One Acknowledged My Loss and Hurt"”; Nina Memarnia et al., "'It Felt Like It Was Night All the Time': Listening to the Experiences of Birth Mothers Whose Children Have Been Taken into Care or Adopted," Adoption \& Fostering 39, no. 4 (December 2015): 303-17, https://doi.org/10.1177/0308575915611516; Riggs and Willsmore, “Experiences of Disenfranchised Grief Arising from the Unplanned Termination of a Foster Placement," 55-66; Corie G. Hebert and Heidi Kulkin, “Attending to Foster Parent Grief: Exploring the Use of Grief Awareness Training for Child Welfare Workers," Adoption \& Fostering 40, no. 2 (July 2016): 128-39, https://doi.org/10.1177/0308575916644169.

${ }^{46}$ John Murphy, “Memory, Identity and Public Narrative: Composing a Life-Story after Leaving Institutional Care, Victoria, 1945-83," Cultural and Social History 7, no. 3 (September 2010): 297-314, https://doi.org/10.2752/147800410X12714191853229; Cate O'Neill, Vlad Selakovic, and Rachel Tropea, “Access to Records for People Who Were in Out-of-Home Care: Moving beyond 'Third Dimension' Archival Practice," Archives and Manuscripts 40, no. 1 (March 2012): 29-41, https://doi.org/10.1080/01576895.2012.668841; Swain and Musgrove, "We are the Stories We Tell about Ourselves," 4-14.

${ }^{47}$ Fletcher, "Life inside Westbrook Children's Home, from the perspective of a survivor" ${ }^{48}$ Stokes, Westbrook, 328.

${ }^{49}$ Fletcher, "Life inside Westbrook Children's Home, from the perspective of a survivor" ${ }^{50}$ Swain and Musgrove, "We Are the Stories We Tell about Ourselves"; Vehkalahti, "Dusting the Archives of Childhood.", page 430-445. 
${ }^{51}$ Senate Community Affairs References Committee, “Lost Innocents: Righting the Record Report on Child Migration"; Senate Community Affairs References Committee, "Forgotten Australians: A Report on Australians Who Experienced Institutional or out-ofHome Care as Children."

${ }^{52}$ Ben Jones, "The Uses of Nostalgia: Autobiography, Community Publishing and Working Class Neighbourhoods in Post-War England," Cultural and Social History 7, no. 3 (September 2010): 355, https://doi.org/10.2752/147800410X12714191853346.

${ }^{53}$ Shurlee Swain, "Institutionalized Childhood: The Orphanage Remembered," The Journal of the History of Childhood and Youth 8, no. 1 (2015): 17-33, https://doi.org/10.1353/hcy.2015.0013; Jones, "The Uses of Nostalgia"; Robert Smith, “Rescripting Criminal Identity: A 'Close Reading' of Contemporary Biographies of British Criminals as Entrepreneurship Discourse," Journal of Enterprising Communities: People and Places in the Global Economy 7, no. 4 (October 14, 2013): 316-39, https://doi.org/10.1108/JEC-09-2012-0051.

${ }^{54}$ Grace Giorgio, "Traumatic Truths and the Gift of Telling," Qualitative Inquiry 15, no. 1 (January 2009): 153, https://doi.org/10.1177/1077800408318300.

${ }^{55}$ Fletcher and Jorgensen, Brutal, 180.

${ }^{56}$ Attig, "Disenfranchised Grief Revisited." Pages 197-215.

57 Janet Argall, Australia's Shame, Four Corners (Australian Broadcasting Corporation, 2016), http://www.abc.net.au/4corners/australias-shame-promo/7649462; Mark Willacy, "The Watch House Files," Text, ABC News, May 13, 2019, https://www.abc.net.au/news/201905-13/hold-the-watch-house-files/11046190. 